\section{Whaling ban versus science}

\section{London \& Tokyo}

NEXT week, an annual ritual will be acted out in Reykjavik, Iceland. At a meeting of the International Whaling Commission (IWC), the language of science will be used to debate a question that actually is dominated by ethical and economic concerns: should the great whales be hunted commercially?

On one side stand the anti-whaling IWC members, whose populations generally disapprove of the killing of whales - a majority that includes the United States and Britain. On the other stand Iceland, Norway and Japan, where coastal communities that once relied upon whaling for their livelihoods have been forced into economic decline by the present moratorium on commercial whaling.

The IWC, however, was not set up to address the ethics of whaling, nor to ensure the economic well-being of whaling communities, but rather to regulate whaling according to scientific principles so as to conserve whale populations. In the past, antiwhaling nations have used uncertainties in the understanding of whale population biology to block any commercial whaling, but IWC scientists are now on the verge of producing a computer model designed to set catch quotas that do not endanger whale populations. This accomplishment will make it extremely difficult to oppose all commercial whaling within the framework of the IWC.

The current commercial moratorium on whaling came into force in 1986 (although Norway and Japan continued commercial whaling for another two years). The argument behind the ban was that the techniques the IWC had been using to set quotas for whale catches were inadequate: there was a danger that whale stocks could be seriously depleted, even by catches within the limits set by the IWC.

Since the ban has been in force, the IWC's scientific committee has been reassessing the size of whale stocks around the world, and working on a 'revised management procedure' to replace the old quota-setting system. The whaling nations are impatient for this to be put in place, so that they can resume commercial hunting of the minke whale, the smallest but most numerous of the great whales.

Biologists on the scientific committee have been developing five separate computer models based on whale population dynamics. They have been asked by the IWC to produce a single model that can be used to set quotas that are large enough and stable enough from year to year to support a commercial whale fishery, yet that will still protect whale stocks from depletion. The biologists hope to decide on a single model in time for next week's IWC meeting.

Once a revised management procedure is in place, the argument in favour of maintaining the ban will be difficult to sustain under

the IWC's constitution. The IWC is for "the regulation of whaling, not the prohibition of whaling," says Jan Arvesen, Norway's IWC commissioner.

The scientific committee is now meeting in closed session in Reykjavik. The full IWC, meeting from 27 to 31 May, must decide whether to adopt the management procedure put forward by its scientists. If it does so, the scientific committee must then conduct further detailed simulations with the model before it can be used to set real catch limits. This could take at least another year.

US and British delegates to the IWC meet-

\section{IMAGE UNAVAILABLE FOR COPYRIGHT REASONS}

Can Minke whales be hunted commercially without endangering their populations?

ing are under public pressure to block the adoption of a management procedure, which would open the door to future commercial whaling. Some whaling nations are worried that this pressure may lead delegates from the anti-whaling countries to throw up various objections to the scientists' computer models in order to delay the adoption or use of any new management procedure.

Kevin Chu, from the US State Department, denies that the US delegation intends to "hide behind the science". The IWC scientific committee has made good progress towards developing a workable computer model, he admits, but he argues that more work must be done before the model is used to set quotas for real catches.

The whaling nations also expect to hear questions about whether the methods used to kill whales are humane - a subject that raises the hackles of the Icelanders, Norwegians and Japanese. "Are killing methods in the slaughterhouses of Chicago humane?" Arvesen retorts. "If they think there is a humane method of killing cows, we will take up the same method for whaling," says Fukuzo Nagasaki, scientific adviser to the Japanese delegation.

The United States may also find its role as the 'world policeman' of the whaling issue undermined by events in Reykjavik. Alone among the anti-whaling nations, the United States has legislation that can be used to apply economic sanctions against countries defying the IWC, or endangering whale populations. But the US delegation must this year reapply to the IWC for permission for its Alaskan Inuit population to catch 40 bowhead whales a year for the next three years. This 'aboriginal subsistence whaling' is not affected by the commercial moratorium, but catches must be approved by the IWC. As the bowhead is an endangered species, US officials are bracing themselves for some opposition to their request.

Chu defends the US bowhead catch, saying that the stock is one of the best studied whale populations, and has been growing at a rate of three per cent a year, despite the annual Inuit catch.

Chu's argument does not necessarily contradict his assertion that the knowledge of minke populations is insufficient to sanction 들 a resumption of commercial whaling - the positions of

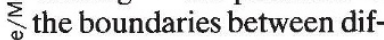
\& ferent minke stocks are not well defined. But the appar$\circlearrowleft$ ent inconsistency will make an appealing target for the whaling nations, particularly for Iceland, the nation now pressing most strongly for a resumption of whaling. Iceland intends to ask for an interim commercial quota for 192 minke whales (from a stock of some 28,000 whales) and 91 fin whales (from a stock of 15-16,000) from the central North Atlantic over the coming year. Judging from the response to previous similar requests, this is unlikely to be accepted.

The debate may not come to a head this year. The anti-whaling nations want to delay any decision on the management procedure, and the scientific committee may not be able to choose a computer model this year. But the desire to defer the issue must be weighed against the longstanding threat by the whaling nations to leave the IWC.

Arni Kolbiensson, secretary-general of the Icelandic fisheries ministry, says that Iceland joined the IWC as a "resource utilization organization". If the IWC fails to conform to that description, he says, Iceland will be forced to reconsider its membership. Whether this threat proves to be more serious than those made in previous years remains to be seen.

Nagasaki is convinced that some IWC nations are using the development of the management procedure as a delaying tactic. And some members of the scientific committee wish privately that the IWC's constitution would allow the true argument - the ethical concerns of the antiwhaling countries versus the economic agenda of the whaling nations - to be debated openly. As one committee member observes, it would be "about time, and much more honest", if the delegates next week in Reykjavik focused on the real issues that concern them, rather than the finer points of whale population dynamics.

Peter Aldhous \& David Swinbanks 